\title{
Nomenclature of equine hoof measurements - a systematic literature review
}

\author{
Lina Sellke, Bianca Patan-Zugaj and Kirsti Witter \\ Institute of Topographic Anatomy, University of Veterinary Medicine Vienna, Austria
}

\begin{abstract}
Summary: Measurements of equine hooves are taken in order to assess hoof conformation, to describe changes to the hoof during disease or in relation to trimming and shoeing. Unfortunately, the terms used for the different dimensions of hoof structures differ widely. We conducted a systematic literature review with the aim of collecting terms used for hoof measurements, and to analyze the findings. Our body of literature consisted of papers and recommended reference books, written in both English and in German over the past 10 years. More than 600 scientific papers were found using the search string "TITLE-ABS-KEY (lequine OR horse) AND hoof) AND PUBYEAR > 2009 AND (LIMIT-TO (SUBJAREA, "VETE"))" in Scopus ${ }^{\circledR}$. Additionally, 5 handbooks were taken into account. A total of 80 Distances, 24 Angles, 34 Ratios and 16 Other measures (e.g. area of sole surface, mediolateral hoof balance) were identified. The highest number of entries (49) was recorded for the caudal angle between Pars dorsalis of the hoof and the ground line, termed often as hoof angle, dorsal hoof wall angle, or toe angle (10 English/2 German terms in total). The length of the Facies solearis, Distance between the outer extent of Pars dorsalis and dorsal cortex of Phalanx distalis; and the caudal angle between Margo solearis of Phalanx distalis and the ground line were classified as measures with highly inconsistent nomenclature (terms/entries of measure 16/25, 17/28 and 17/30, respectively). The most consistent nomenclature was recorded for the term Heel length (12/12). One should be aware of the fact that different terms might be used for the same item or that the same term might signify different measures in different publications. Established terms are not always anatomically correct. We recommend defining every used term in detail, in both written form using correct anatomical nomenclature, and in a figure. The same terms should be used in all publications of one working group. Suggestions for consistent terminology of 15 commonly used measurements in English and German are provided in the paper.
\end{abstract}

Keywords: horse, terminology, hoof, dimension, distance, angle, ratio

Citation: Sellke L., Patan-Zugaj B., Witter K. (2020) Nomenclature of equine hoof measurements - a systematic literature review. Pferdeheilkunde 36, 238-251; DOI 10.21836/PEM20200306

Correspondence: Mag. med. vet. Lina Sellke, University of Veterinary Medicine Vienna, Institute of Topographic Anatomy, Veterinärplatz 1 , 1210 Vienna, Austria; lina.sellke@vetmeduni.ac.at

Submitted: January 22, 2020 | Accepted: March 24, 2020

\section{Introduction}

Dimensions and angles of the equine hoof are measured in order to assess and classify hoof shape (Gordon et al. 2013, Thieme et al. 2015a), to quantify changes developing during training or during the course of an illness and its treatment (Cruz et al. 2006, Decurnex et al. 2009), and to measure the effect of trimming or application of different horseshoes on the hoof conformation (Tanaka et al. 2015, Amitrano et al. 2016, Hagen et al. 2017). Measurements can be taken directly from the living hoof (Bellenzani et al. 2012, Souza et al. 2016), from scaled photographs (Kane et al. 1998, White et al. 2008, Hampson et al. 2010, Dyson et al. 2011 1), from X-ray plates (Cripps and Eustace 1999, Kummer et al. 2004, Eliashar 2012, Thieme et al. 2015a) and from 3D reconstructions of CT or MRI series (Labens et al. 2013, Grundmann et al. 2015). Unfortunately, the terms used for the different Distances, Angles and Ratios as well as Others (areas, points and axes) of hoof structures differ widely in English and German literature. In some cases, there are even term differences within single chapters of the same handbook (Baxter 2011) and in different publications by the same author (Hampson et al. $2010,2013)$. For the definition of measurements, traditional "farrier terms" such as "toe" for Pars dorsalis ungulae are often used (i.a. Stachurska et al. 2011, Holroyd et al. 2013, Lewis et al. 2014, Faramarzi et al. 2018). Therefore, the consolidated anatomical nomenclature is not always helpful for a clear understanding of literature dealing with hoof biometry.

The aim of our study was to perform a comprehensive systematic review of the recent literature written in English and German, and to collect the terms and definitions used for all assessed measurements of the equine hoof. From this information, a proposal for a standard terminology of the most popular hoof distances and angles shall be developed.

\section{Material and methods}

Sources and Search

The database Scopus ${ }^{\circledR}$ (www.scopus.com) was searched using the search string "TITLE-ABS-KEY (( equine OR horse) AND hoof) AND PUBYEAR > 2009 AND ( LIMIT- TO (SUBJAREA, "VETE" ) )" on February, 21 st, 2019. 614 Papers published from January, 1st, 2010 to February, 21 1 st 2019 were con- 
sidered for further analysis. Additionally, five standard books on equine hooves and limbs, recommended by experienced equine orthopaedists available at the Library of the University of Veterinary Medicine Vienna, Austria, were taken into account. The included books were "Adams \& Stashaks Lameness in Horses" (Baxter 2011 ), "Lameness in the Horse" (Ross and Dyson 2011), "Equine Podiatry" (Floyd and Mansmann 2007), "Der Huf" (Litzke and Rau 2012) as well as "Adams Lahmheiten der Pferde" (Stashak 2010).

All publications were hand-searched individually by LS for the use of internal and external measurements of horse and donkey hooves and their nomenclature. The workflow of the literature review is depicted in Figure 1.

The measurements were itemized and each term, definition and scope of application was listed. Additionally, all distances, angles and terms used more than once were presented graphically.

A list of suggested terms was developed for the most commonly used measurements.

\section{Statistics}

The total number of papers found by the search string defined above, and the number and classification of papers meeting the inclusion criteria, were recorded. All publications were classified by the language and type of publication (original and review; books or papers), and the number of publications per category was listed. The average number of measurements per paper was calculated.
The total number of different measurements, the number of measurements per category and the number of terms used for every single measurement was recorded. The most commonly used terms were identified by counting the publications mentioning them. Constant and inconstant use of nomenclature was recorded by comparing the number of entries and the number of used terms. The number and method (text definition vs. scheme) of definitions for each measurement was documented. Latin terms used for hoof structures in this review are based on the Nomina anatomica veterinaria (NAV, 2017) and presented in Figure 2, as well as English and German terms commonly used in a veterinary context.

\section{Results}

\section{Search results and statistics}

The Scopus ${ }^{\circledR}$ search using the keywords equine/horse and hoof under the subtopic Veterinary Medicine generated 614 papers published within the last ten years. In the first screening, 85 papers with hoof measurements were identified. Eleven publications were excluded, nine because they were written in Portuguese and two because detailed analysis revealed that no measurements were used. Due to the focus of this study on measurements, publications dealing with measures on donkey hooves were included. The full list of 79 publications that were eventually included in this study, i.e. 74 papers which met the inclusion criteria and the five handbooks, is given in Table 1. The assigned numbers will be used as references in the Results section of this study. Sixty-three original papers $(2-4,8,10,12-22,25-34,36-42$, $44-71,73,73)$ and two educational papers with original mea-

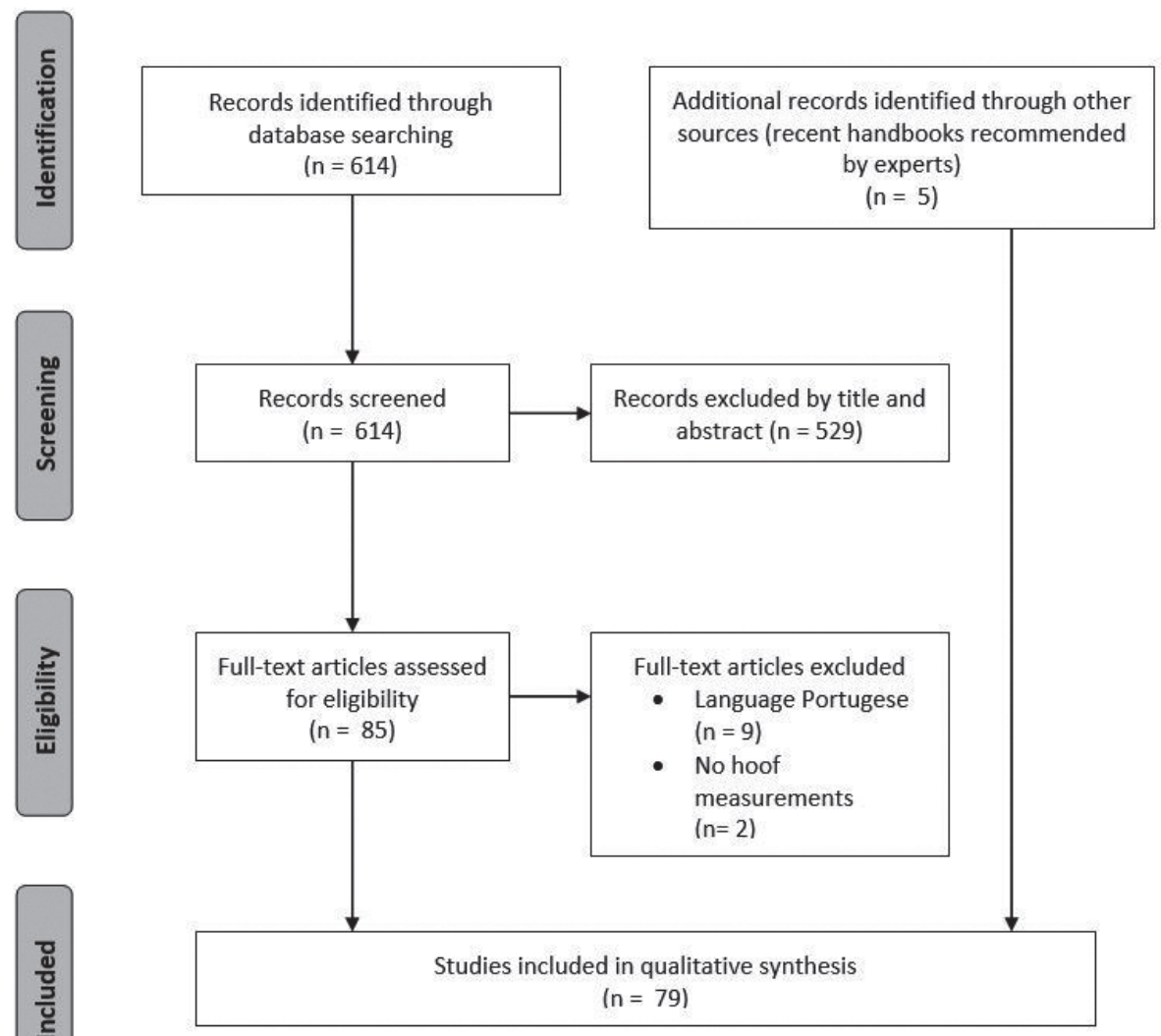

Fig. 1 Preferred Reporting Items for Systematic Reviews and Meta-Analyses (PRISMA) (Moher et al. 2009) | Flussdiagramm zur systematischen Literaturrecherche (PRISMA) (Moher et al. 2009) 
Table 1 Publications included in this study and numerical code for Results. For complete biographical references, see References. $\mid$ In diese Studie einbezogene Publikationen und Nummernschlüssel für das Kapitel "Results". Vollständige Literaturangaben siehe "References"

\begin{tabular}{|c|c|c|c|c|c|}
\hline No. & Citation & Digital object identifier (DOI)/ISBN/ISSN & No. & Citation & Digital object identifier (DOI)/ISBN/ISSN \\
\hline 1 & van Eps 2010 & 10.1016/i.cveq.2009.12.011 & 40 & Jansová et al. 2015 & 10.1016/i.jevs.2014.11.008 \\
\hline 2 & Hampson et al. 2010 & $10.1111 /$ /.1751-0813.2010.00554.x & 41 & Faramarzi et al. 2015 & $10.1111 /$ evj.12375 \\
\hline 3 & van Heel et al. 2010 & $10.1111 /$ /.2042-3306.2010.00064.x & 42 & Grundmann et al. 2015 & $10.1111 / \mathrm{evj} .12340$ \\
\hline 4 & Bhatnagar et al. 2010 & 10.1016/i.jevs.2010.05.004 & 43 & Thieme et al. $2015 b$ & 10.21836/PEM20150201 \\
\hline 5 & Eustace 2010 & 10.1016/i.cveq.2010.06.005 & 44 & Tanaka et al. 2015 & $10.1294 /$ jes.26.67 \\
\hline 6 & O'Grady 2010 & 10.1016/i.cveq.2010.04.008 & 45 & Hagen et al. 2015 & 10.21836/PEM20150605 \\
\hline 7 & Reilly $2010 a$ & 10.1016/i.jevs.2010.07.013 & 46 & Goulet et al. 2015 & $10.1111 /$ vru. 12280 \\
\hline 8 & Reilly $2010 b$ & 10.1016/i.jevs.2010.07.020 & 47 & Thieme et al. $2015 a$ & 10.1016/i.tvil.2015.10.005 \\
\hline 9 & Floyd 2010 & 10.1016/i.jevs.2010.10.002 & 48 & Souza et al. 2016 & $10.1590 / 1678-4162-8848$ \\
\hline 10 & Mansmann et al. 2010 & 10.1016/i.jevs.2010.11.007 & 49 & Hagen et al. 2016 & 10.1016/i.jevs.2015.12.001 \\
\hline 11 & Karle et al. 2010 & ISSN 09728988 & 50 & Hüppler et al. 2016 & 10.1016/i.jevs.2015.12.009 \\
\hline 12 & Ronchetti et al. 2011 & 10.1136/vr.c5993 & 51 & Caldwell et al. 2016 & 10.1016/i.tvil.2015.10.003 \\
\hline 13 & Dyson et al. 2011 a & $10.1111 /$ /.2042-3306.2010.00162.x & 52 & Wilson et al. 2016 & $10.1111 /$ evj. 12378 \\
\hline 14 & Hampson et al. 2011 & 10.2460/ajvr.77.9.983 & 53 & Drumond et al. 2016 & 10.21836/PEM20160203 \\
\hline 15 & Stachurska et al. 2011 & ISSN 08604037 & 54 & de Zani et al. 2016 & $10.1111 /$ evj.12411 \\
\hline 16 & Collins et al. 2011 & $10.1111 / j .2042-3306.2010 .00312 . x$ & 55 & Colborne et al. 2016 & $10.1080 / 00480169.2015 .1068138$ \\
\hline 17 & Parés i Casanova 2011 & 10.1016/i.jevs.201 1.03.020 & 56 & Amitrano et al. 2016 & 10.2460/ajvr.77.5.527 \\
\hline \multirow[t]{2}{*}{18} & \multirow[t]{2}{*}{$\begin{array}{l}\text { Hertsch and Teschner } \\
2011\end{array}$} & \multirow[t]{2}{*}{ ISSN 14341239} & 57 & Dijkstra et al. 2016 & 10.1016/i.jevs.2016.07.011 \\
\hline & & & 58 & Faramarzi et al. 2017 & 10.3415/VCOT-16-11-0158 \\
\hline 19 & Cayion el ar. 2011 & 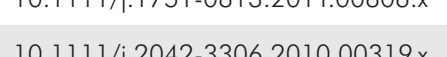 & 59 & de Souza et al. 2017 & $10.1590 / 0103-8478 c r 20160945$ \\
\hline 20 & Namisey el ain. Zuti & $10.1171 / 1.2042-0000.2010 .00017 . x$ & 60 & El-Shafaey et al. 2017 & 10.12681/jhvms.15543 \\
\hline 21 & Dysori ter un., 20170 & $90.1010 / . \ln \mid 1.2010 .11 .010$ & 61 & Pauwels et al. 2017 & $10.1111 / v r u .12443$ \\
\hline 22 & $\begin{array}{l}\text { Parés i Casanova and } \\
\text { Oosterlinck } 2012\end{array}$ & 10.1016/i.jevs.2011.08.020 & 62 & Ribeiro et al. 2017 & 10.1016/j.jevs.2016.10.007 \\
\hline 23 & Eggleston 2012 & 10.1016/j.cveq.2012.05.001 & 63 & Leśniak et al. 2017 & 10.3390/ani7040029 \\
\hline 24 & Eliashar 2012 & 10.1016/i.cveq.2012.06.001 & 64 & $\begin{array}{l}\text { Labuschagne et al. } \\
2017\end{array}$ & 10.1016/i.jevs.2016.11.013 \\
\hline 25 & Bellenzani et al. 2012 & 10.2460/ajvr.73.11.1735 & 65 & Hagen et al. 2017 & 10.1016/i.jevs.2017.01.014 \\
\hline 26 & Hampson et al. 2013 & $10.1111 /$ / $1.1751-0813.2012 .00995 . x$ & 66 & Tocci et al. 2017 & 10.1515/jvetres-2017-0049 \\
\hline 27 & Gordon et al. 2013 & 10.1016/i.jevs.2012.05.058 & 67 & Mullard et al. 2018 & 10.1111/eve.13004 \\
\hline 28 & Cust et al. 2013 & 10.1111 /avj.12012 & 68 & Hagen et al. $2018 a$ & 10.4314/ovi.v8i1.15 \\
\hline 29 & Holroyd et al. 2013 & 10.1016/j.tvi|.2012.07.012 & 69 & Pezzanite et al. 2018 & $10.1111 /$ evj.13050 \\
\hline 31 & Kolstrung et al. 2013 & 10.1016/i.jevs.2012.07.001 & 70 & $\begin{array}{l}\text { Tracey and McClure } \\
2018\end{array}$ & 10.1111/eve.12768 \\
\hline 32 & Patan-Zugaj et al. 2013 & 10.21836/PEM20130302 & 71 & Van Thielen et al. 2018 & 10.1111/ahe.12326 \\
\hline 33 & $\begin{array}{l}\text { Holden-Douilly et al. } \\
2013\end{array}$ & 10.1016/i.tvil.2013.02.004 & 72 & Bras and Redden 2018 & 10.1016/i.cveq.2018.04.015 \\
\hline & & & 73 & Walliser et al. 2018 & 10.21836/PEM20180502 \\
\hline 34 & Simonato et al. 2013 & $737 \times 2013000300003$ & 74 & Faramarzi et al. 2018 & 10.1016/i.jevs.2018.08.012 \\
\hline 35 & $\begin{array}{l}\text { Sherlock and Parks } \\
2013\end{array}$ & $10.1111 /$ eve.12065 & 75 & $\begin{array}{l}\text { Floyd and Mansmann } \\
2007\end{array}$ & ISBN 978-0721603834 \\
\hline 36 & Weishaupt et al. 2013 & 10.1016/j.tvi|.2013.09.043 & 76 & Stashak 2010 & ISBN 978-3-37944-0219-9 \\
\hline 37 & Waldern et al. 2013 & 10.1016/i.tvil.2013.09.042 & 77 & Baxter 2011 & ISBN 978-0-8138-1549-7 \\
\hline 38 & Lewis et al. 2014 & 10.1016/i.jevs.2014.04.010 & 78 & Ross and Dyson 2011 & ISBN 978-1416060697 \\
\hline 39 & Taylor et al. 2014 & 10.1016/j.jevs.2013.08.052 & 79 & Litzke and Rau 2012 & ISBN-987-3-8304-1074-4 \\
\hline
\end{tabular}


surement data $(9,23)$ were referred to as "original publications". Nine reviews and educational papers $(1,5-7,11,24,35,43$, 72), as well as the five selected handbooks (75-79), were classified as reviews. Seventy-two publications were written in English $(1-17,19-31,33-42,44,46-72,74,75,77,78)$ and seven in German $(18,32,43,45,73,76,79)$.

A total of 154 different measurements, falling into the categories: Distances (80), Angles (24), Ratios (34) and measurements of the category Others (including areas, points and axes) (16) were identified. Dimensions which were each mentioned in only one
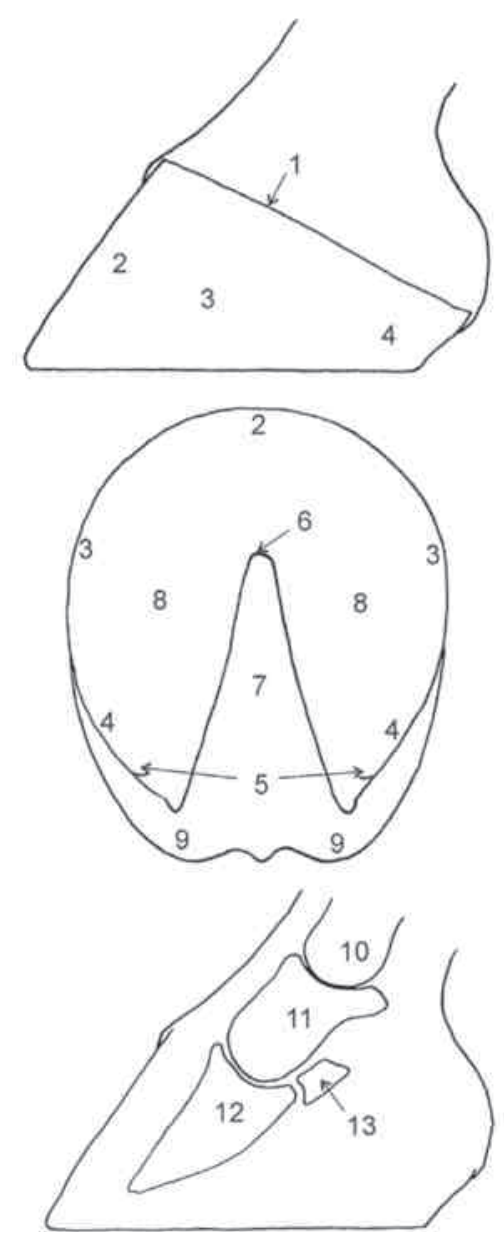

Fig. 2 Nomenclature of hoof structures: Schematic illustration of the external structures of the hoof in lateral and sole aspect, as well as the internal structures in lateral aspect. Legend: 1, Margo coronalis, coronary band, coronet; 2, Pars dorsalis, toe; 3, Pars lateralis/medialis, quarter; 4, Pars mobilis lateralis/medialis, heel; 5, Pars inflexa lateralis/medialis, bar; 6, Apex cunei, frog tip; 7, Cuneus ungulae, frog; 8 , Solea, sole; 9, Torus ungulae, bulb; 10, Os compedale, Phalanx proximalis, $\mathrm{P} 1$, fetlock bone, long pastern bone, proximal phalanx; 11, Os coronale, Phalanx media, P2, short pastern bone, middle phalanx; 12, Os ungulare, Phalanx distalis, P3, coffin bone, distal phalanx; 13, Os sesamoideum distale, navicular bone. | Nomenklatur der Strukturen des Hufes: Schematische Darstellung der äußeren Strukturen des Hufs in Lateralund Sohlenansicht, sowie der inneren Strukturen von lateral. Legende: 1, Margo coronalis, Kronrand; 2, Pars dorsalis, Zehenteil, Zehe; 3, Pars lateralis/medialis, Seitenteil; 4, Pars mobilis lateralis/medialis, Trachte; 5, Pars inflexa lateralis/medialis, Eckstrebe; 6, Apex cunei, Strahlspitze; 7, Cuneus ungulae, Strahl; 8, Solea, Sohle; 9, Torus ungulae, Ballen; 10, Os compedale, Phalanx proximalis, P1, Fesselbein; 11, Os coronale, Phalanx media, P2, Kronbein; 12, Os ungulare, Phalanx distalis, P3, Hufbein; 13, Os sesamoideum distale, Strahlbein. paper, respectively, included 39 of the Distances, 6 of the Angles, 25 of the Ratios and 9 of the category Others. All distances, angles and terms mentioned more than once are summarized in Figure 3. The complete list of measurements and definitions can be found as Supplement 1 (https://www.hippiatrika.com/download.htm? id=20200211). On average, 8 hoof measurements were recorded per publication. In 9 publications the authors recorded only 1 hoof measurement $(3,8,10,12,14,31,33,56$, 69), while in 4 publications more than 20 measurements were documented $(26,41,47,58)$. The most commonly used measurements in total were distances $b_{1-3}$ (Fig. 3A) with 32 entries $(1,5,6,9,16,18,23,26,35,39-43,45,46,53,54,58$, $60,62,66,67,70-75,77-79), 9$ of them in reviews. Distance $f($ Fig. 3D) could be found 30 times $(2,11,13,15,19,21,23$, $24,26,29,32,36-38,41,43,47,48,51,57-60,63,64$, $74,75-78), 6$ of them in reviews. The highest number of entries (49) was recorded for angle an (Fig. 3D) $(2-4,9,11,13,16$, 18-21, 23-30, 33-37, 41, 43, 47, 48, 51-53, 55, 57-60, $62-64,68,70-72,74-79), 10$ of them in reviews. The angle ao (Fig. 3C) was found 33 times $(2,6,9,13,16,19,20,23$, $26,35,39-41,43,45,47,49,50,52-54,58,60-62,65,68$, $69,71,72,75,77,79), 7$ of them in reviews. Original papers with a high amount of different measurements were for example studies focusing on hoof conformation $(2,26,29,41,58,64)$ and on measurements of the equine hoof itself (47). The publications with few measurements investigated research questions with specific problems, as for example the correlation between a particular hoof dimension and lameness (69), ratios of different dimensions in relation to laminitis (73) and the correlation between hoof angles and race performance of the same horse (28).

The number of German scientific publications dealing with hoof measurements was low $(18,32,43,45$ 73, 76, 79) during the studied time period. Nineteen out of the 154 measurements (Fig. 3; $a, b_{1-3}, f, i_{1}, m, n, q$, af, ag, ah, am, an, ao, ae, av, ay, three not depicted) were included in German publications, all of them were named with German terms. Some papers also provided terms in English $(29,43,45,73)$. Almost a third (7 out of 19) of the measurements in German publications were mentioned in only one review paper (43).

\section{Consistency and inconsistency of nomenclature}

English terms for the most common measurements (Fig. 3; $b_{1-3}, f$, an, ao) were used inconsistently. For the distances $b_{1-3}$ (Fig. 3A) with 28 entries $(1,5,6,9,16,23,26,35,39-42$, $45,46,53,54,58,60,62,66,67,70-72,74,75,77,78)$ in English publications, 17 different terms were used. For $f$ (Fig. 3D) which was recorded 27 times $(2,11,13,15,19$, $21,23,24,26,29,36-38,41,47,48,51,57-60,63,64$, $74,75,77,78), 6$ terms could be found. The angle an (Fig. 3D) was mentioned in 45 papers $(2-4,9,11,13,16,19-21$, 23-30, 33-37, 41, 47, 48, 51-53, 55, 57-60, 62-64, 68, 70-72, 74, 75, 77, 78) with 11 noted terms; and for the angle ao (Fig. 3C) 17 different terms were used within a total of 30 entries $(2,6,9,13,16,19,20,23,26,35,39-41$, $47,49,50,52-54,58,60-62,65,68,69,71,72,75,77)$. A frequently used dimension, with an extremely inconsistent nomenclature was the measure $c$ (Fig. 3D), which was mentioned in 25 English publications $(2,13,15,19-22,26,27$, $29,38,41,39,40,51,56-58,60,63,66,74,75,77,78)$ 

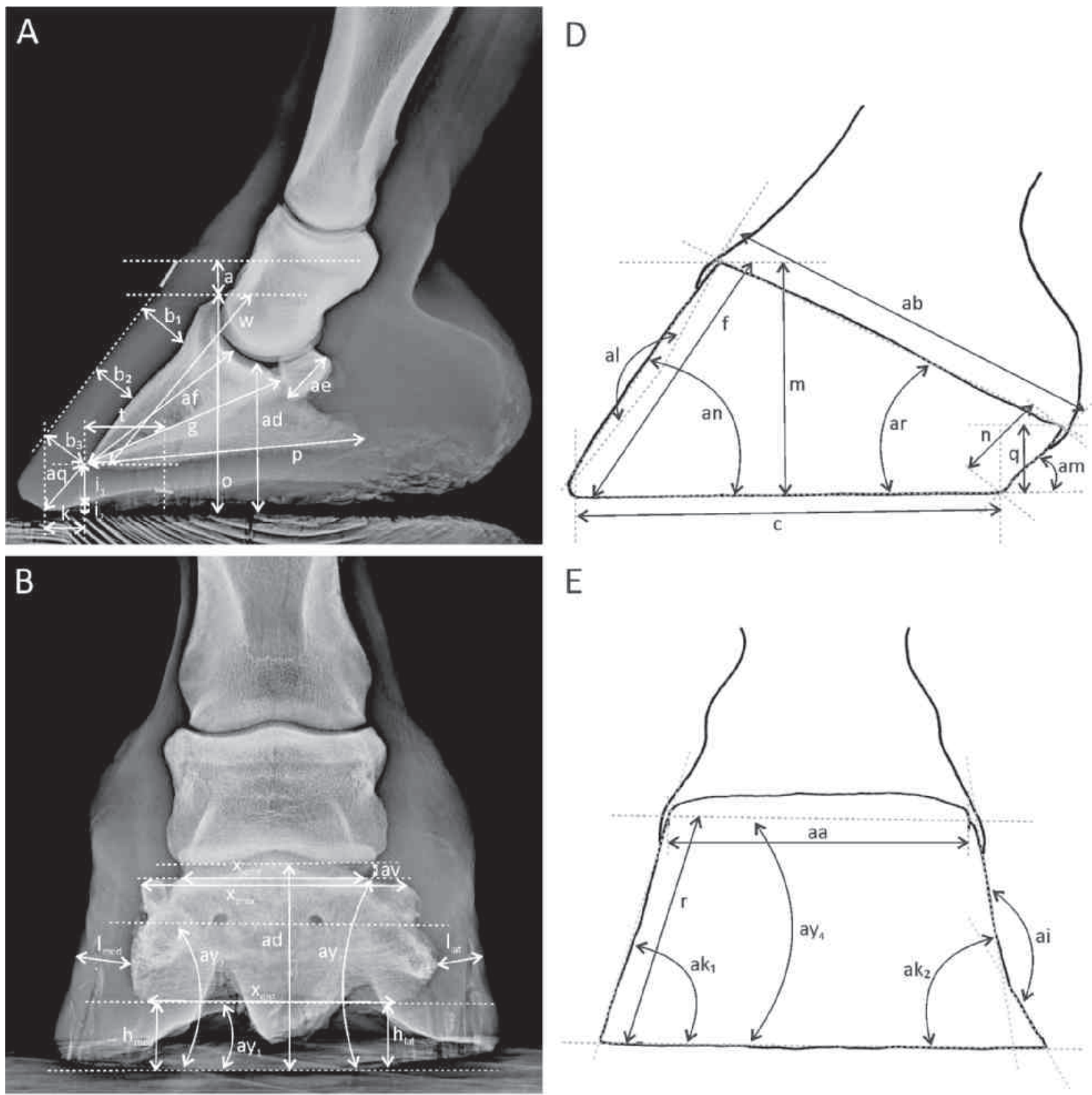

E

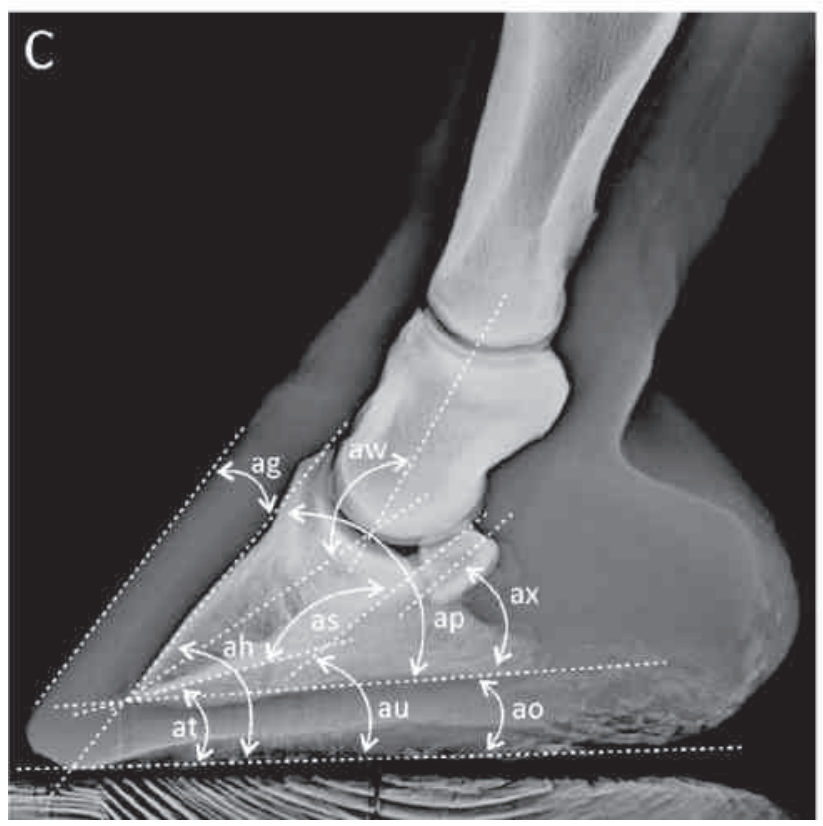

$\mathrm{F}$

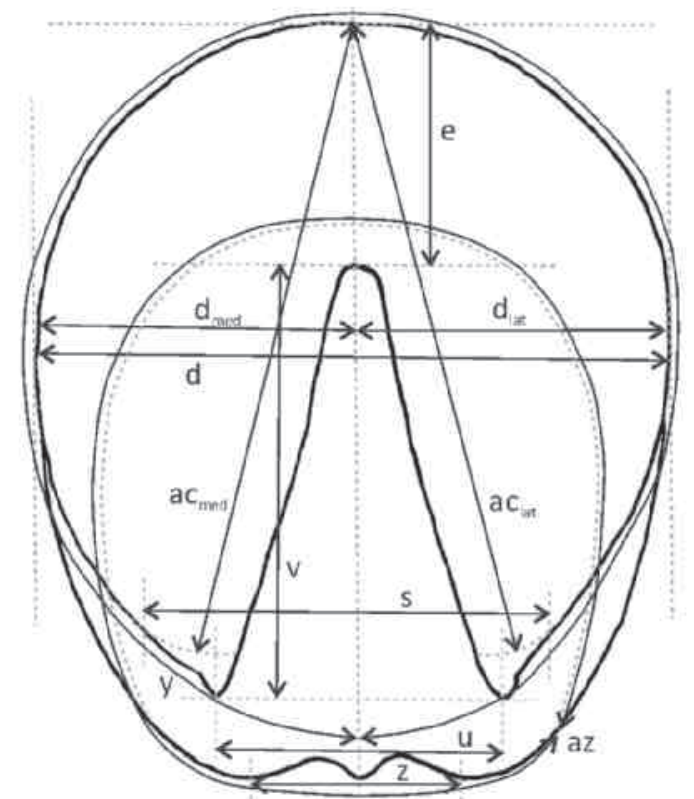


Fig. 3 Measurements in equine hooves: Summary of literature published between January, $1^{\text {st }}, 2010$ and February, $21^{\text {st }}, 2019$. Only angles, distances and terms mentioned more than once are shown. X-ray of the left forelimb digit of a horse in [A] lateromedial view, [B] dorsopalmar view and [C] lateromedial view, [D] lateral, [E] dorsal and [F] solear aspect of the hoof (schematics). Legend: a, Vertical distance between Processus (Proc.) extensorius of and the dorsoproximal end of Pars (P.) dorsalis of the hoof $[A] ; b_{1-3^{\prime}}$ Linear distance between the outermost extent of $P$. dorsalis of the hoof and the dorsal cortex of Phalanx (Ph.) distalis, measured perpendicular to P. dorsalis [A]; C, Length of Facies (F.) contactus of F. solearis [D]; $\mathrm{d}_{\text {med/at' }}$ Linear distance between the sagittal axis and the widest part of P. lateralis/medialis [F]; e, Linear distance between the most dorsodistal extent of P. dorsalis and Apex cunei [F]; $f$, Linear distance from the most dorsoproximal point of $P$. dorsalis and along the hoof wall to the ground line $[D] ; g$, Linear distance between the tip of Ph. distalis and the palmaroproximal end of F. flexoria $[A] ; h_{\text {lat/med' }}$ Vertical distance between Proc. palmaris lateralis/medialis and the ground line $[\mathrm{B}] ; \mathrm{i}_{1+2}$, Vertical distance between the tip of Ph. distalis and the ground; $\mathrm{i}_{1}$, Vertical distance between the tip of Ph. distalis and the distal border of Solea; $i_{2}$, Vertical distance between the distal border of Solea and the ground [A]; $k$, Horizontal distance between the vertical line at the tip of Ph. distalis and the point of $\mathrm{M}$. solearis at which the hoof tilts during movement (breakover point) [A]; $I_{\text {at/med, }}$ Shortest linear distance between the outermost extent of P. lateralis/medialis and Ph. distalis, measured perpendicular to P. lateral/medialis $[\mathrm{B}] ; \mathrm{m}$, Vertical distance between the most dorsoproximal point of Margo (M.) coronalis and the ground line [D]; $\mathrm{n}$, Linear distance between the most palmarolateral/-medial and most distal part of P. mobilis lateralis/medialis [D]; O, Vertical distance between the proximal extent of Proc. extensorius and the ground line $[\mathrm{A}] ; \mathrm{p}$, Distance between the tip of Ph. distalis and the palmarodistal end of Proc. Palmaris $[\mathrm{A}]$; $\mathrm{q}$, Vertical distance between the most palmarolateral/-medial point of M. coronalis at the heel and the ground line [D]; $r$, Linear distance between the most dorsolateral/-medial point of M. coronalis and the ground line, measured along the hoof wall of P.lateralis/medialis [E]; s, Linear distance between the palmarolateral and palmaromedial end of F. contactus of F. solearis $[\mathrm{F}] ; \mathrm{t}$, Horizontal distance between the vertical line at the tip of Ph. distalis and barium marked Apex cunei $[A]$; u, Linear distance between the most palmarolateral and palmaromedial end of Cuneus ungulae [F]; $v$, Shortest linear distance between Apex cunei and the line connecting the palmar ends of Cuneus ungulae $[F] ; w$, Linear distance between the dorsoproximal end of Proc. extensorius and the tip of Ph. distalis $[\mathrm{A}] ; \mathrm{x}$, Horizontal distance between the lateral and medial border of Ph. distalis; $\mathrm{x}_{\text {ioint' }}$ measured at F. articularis; $x_{\text {prox }}$, measured at the proximal end; $x_{\text {dist' }}$ measured at the distal end $[B] ; y$, Full circumference of $F$. solearis $[F]$; $z$, Transverse distance between the most convex parts of Torus ungulae [F]; aa, Distance between the most lateral and most medial part of M. coronalis [E]; ab, Projected length of M. coronalis in lateromedial aspect, measured between the most dorsoproximal and palmarodistal point [D]; ac lat/med Linear distance between the tip of Ph. distalis and the curved palmar end of P. inflexa lateralis/medialis at F. solearis [F]; ad, Shortest vertical distance between F. articularis of $\mathrm{Ph}$. distalis and the ground $[\mathrm{B}]$; ae, Longest distance between the proximal and distal end of Os sesamoideum distale, in lateral view $[\mathrm{A}]$; af, Shortest distance between joint surface of Art. interphalangea distalis and the tip of Ph. distalis $[\mathrm{A}]$; ag, Angle between P. dorsalis of the hoof and the dorsal cortex of Ph. distalis [C]; ah, Caudal angle between the dorsal cortex of Ph. distalis and the ground line [C]; ai $\left.\right|_{\text {lat } / \text { med }}$ Angle

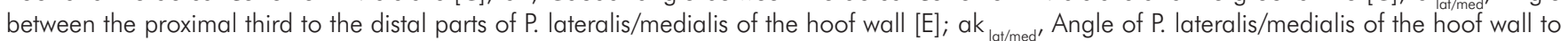
the ground line; $\mathrm{ak}_{1}$, measured between the entire P. lateralis/medialis and the ground line; $\mathrm{ak}_{2}$, measured between the proximal third of P. lateralis/medialis and the ground line [E]; al, Angle between the proximal third to a distal angulation of P. dorsalis of the hoof wall [D]; am, Caudal angle between P. mobilis lateralis/medialis and the ground line [D]; an, Caudal angle between P. dorsalis of the hoof and the ground line [D]; ao, Caudal angle between M. solearis of Ph. distalis and the ground line $[\mathrm{C}]$; ap, Caudal angle between the dorsal cortex and $\mathrm{M}$. solearis of Ph. distalis $[\mathrm{C}]$; aq, Linear distance between the tip of Ph. distalis and the point of $\mathrm{M}$. solearis at which the hoof tilts during movement (breakover point) $[\mathrm{A}]$; ar, Angle between M. coronalis and the ground line in lateral aspect [D]; as, Angle between Planum cutaneum and F. flexoria of Ph. distalis in lateromedial view [C]; at, Angle between Planum cutaneum of Ph. distalis and the ground line in lateromedial view [C]; au, Angle between $\mathrm{F}$. flexoria of Ph. distalis and the ground line in lateromedial view [C]; av, Angle between a line parallel to Trochlea phalangis mediae and a line parallel to F. articularis phalangis distalis [B]; aw, Angle between the long axis of Ph. media and the line through the tip of Ph. distalis and the middle of Art. interphalangea distalis [C]; ax, Angle between the proximodistal axis of Os sesamoideum distale and the ground line [C]; ay, Lateromedial symmetry: $\mathrm{ay}_{1}$, Angle between the distal border of Ph. distalis and the ground line in dorsopalmar view [B]; ay ${ }_{2}$ Angle between $\mathrm{F}$. articularis of Ph. distalis and the ground line in dorsopalmar view $[\mathrm{B}]$; ay $_{3_{3}}$ Angle between a line through Foramen solearie laterale and mediale of Ph. distalis and the ground line in dorsopalmar aspect $[\mathrm{B}]$; $\mathrm{ay}_{4^{\prime}}$, Angle between a line parallel to M. coronalis and the ground line in dorsal aspect [E]; az, Full circumference at M. coronalis [F]. I Messungen am Pferdehuf: Zusammenfassung der zwischen 01.01.2010 und 21.02.2019 publizierten Literatur. Es sind nur Längen- und Winkelmaße sowie andere Begriffe dargestellt, die in mehr als einer Publikation enwähnt wurden. [A] Röntgenbild der linken Vorderzehe eines Pferdes im lateromedialen Strahlengang, [B] Röntgenbild der linken Vorderzehe eines Pferdes im dorsopalmaren Strahlengang, [C] Röntgenbild der linken Vorderzehe eines Pferdes im lateromedialen Strahlengang, [D] Schemazeichnung der linken Vorderzehe eines Pferdes in Lateralansicht, [E] Schemazeichnung der linken Vorderzehe eines Pferdes in Dorsalansicht, [F] Schemazeichnung der linken Vorderzehe eines Pferdes in Sohlenansicht. Legende: a, Vertikaler Abstand zwischen Processus (Proc.) extensorius und dem dorsoproximalen Ende von Pars (P.) dorsalis [A]; $b_{1-3^{\prime}}$ Linearer Abstand zwischen der äußeren Grenze von P. dorsalis und dem dorsalen Kortex von Phalanx (Ph.) distalis, senkrecht zu P. dorsalis gemessen [A]; c, Länge der Facies (F.) contactus der F. solearis [D]; $d_{\text {med/la' }}$ Linearer Abstand zwischen der Sagittalachse des Hufs und der jeweils weitesten Stelle von P. lateralis/medialis [F]; e, Linearer Abstand zwischen dem dorsodistalen Ende von P. dorsalis und Apex cunei [F]; f, Linearer Abstand zwischen dem dorsoproximalen Ende von P. dorsalis und der Bodenlinie, entlang der Hufwand gemessen [D]; g, Linearer Abstand zwischen der Spitze von Ph. distalis und dem palmaroproximalen Ende der F. flexoria [A]; $h_{\text {lat/mea" }}$ Vertikaler Abstand zwischen Proc. palmaris lateralis/medialis und der Bodenlinie [B]; $i_{1+2}$, Vertikaler Anstand zwischen der Spitze von Ph. distalis und der Bodenlinie; $i_{1}$, Vertikaler Anstand zwischen der Spitze von Ph. distalis und der distalen Grenze der Solea; $i_{2}$, Vertikaler Abstand zwischen der distalen Grenze der Solea und der Bodenlinie $[A]$; k, Horizontaler Abstand zwischen der vertikalen Tangente an der Spitze von Ph. distalis und dem Abrollpunkt des Hufs [A]; I med" Kürzester linearer Abstand zwischen der äußeren Grenze von P. lateralis/medialis und Ph. distalis, senkrecht zu P. lateral/medialis gemessen [B]; $m$, Vertikaler Abstand zwischen dem dorsoproximalsten Punkt des Margo (M.) coronalis und der Bodenlinie[D]; n, Linearer Abstand zwischen dem palmarolateralsten/-medialsten Punkt des M. coronalis und dem distalen Ende von P. mobilis lateralis/medialis [D]; o, Vertikaler Abstand zwischen dem proximalen Ende des Proc. extensorius und der Bodenlinie [A]; p, Abstand zwischen der Spitze von Ph. distalis und dem palmarodistalen Ende des Proc. palmaris [A]; q, Vertikaler Abstand zwischen dem palmarolateralsten/-medialsten Punkt des M. coronalis an der Trachte und der Bodenlinie [D]; r, Linearer Abstand zwischen dem dorsolateralsten/-medialsten Punkt des M. coronalis und der Bodenlinie, entlang P. lateralis/medialis gemessen[E]; s, Linearer Abstand zwischen dem palmarolateralen und dem palmaromedialen Ende von F. solearis [F]; t, Horizontaler Abstand zwischen der vertikalen Tangente an der Spitze von Ph. distalis und dem bariummarkierten Apex cunei [A]; u, Linearer Abstand zwischen dem palmarolateralen und palmaromedialen Ende von Cuneus ungulae [F]; v, Kürzestester linearer Abstand zwischen Apex cunei und der Verbindungslinie zwischen den palmaren Enden des Cuneus ungulae [F]; w, Linearer Abstand zwischen dem dorsoproximalen Ende des Proc. extensorius und der Spitze der Ph. distalis [A]; x, Horizontaler Abstand zwischen der lateralen und medialen Kante der Ph. distalis; $x_{\text {joint }}$ gemessen an der F. articularis; $x_{\text {prox }}$ gemessen am proximalen Ende; $x_{\text {dis }}$ gemessen am distalen Ende [B]; $y$, Umfang der F. solearis [F]; $z$, Transversaler Abstand zwischen den beiden maximal konvexen Anteilen des Torus ungulae [F]; aa, Abstand zwischen dem medialsten und lateralsten Punkt des M. coronalis, gemessen 
in Projektion [E]; ab, Projizierte Länge des M. coronalis in Lateralansicht, gemessen zwischen dem dorsoproximalsten und palmarodistalsten Punkt [D]; $a_{\text {lat /med" }}$ Linearer Abstand zwischen der Spitze der Ph. distalis und dem Palmarende der P. inflexa lateralis/medialis auf der F. solearis [F]; ad, Kürzester vertikaler Abstand zwischen F. articularis der Ph. distalis und der Bodenlinie [B]; ae, Größter Abstand zwischen dem proximalen und distalen Ende des Os sesamoideum distale im lateromedialen Strahlengang [A]; af, Kürzester Abstand zwischen F. articularis und der Spitze der Ph. distalis [A]; ag, Winkel zwischen P. dorsalis des Hufs und dem dorsalen Kortex der Ph. distalis [C]; ah, Kaudaler Winkel zwischen dorsalem Kortex der Ph. distalis und der Bodenlinie [C]; ai ${ }_{\text {lat } / \text { med }^{\prime}}$ Winkel zwischen dem proximalen Drittel und dem distalen Anteil der P. lateralis/medialis der Hufwand [E]; ak ${ }_{\text {lat/med" }}$ Winkel zwischen P. lateralis/medialis der Hufwand zur Bodenlinie; ak, gemessen zwischen der gesamten P. lateralis/medialis und der Bodenlinie; $a k_{2}$ gemessen zwischen dem proximalen Drittel der P. lateralis/medialis und der Bodenlinie [E]; al, Winkel zwischen dem proximalen Drittel und dem distalen Anteil der P. dorsalis der Hufwand [D]; am, Kaudaler Winkel zwischen P. mobilis lateralis/medialis und der Bodenlinie [D]; an, Kaudaler Winkel zwischen P. dorsalis und der Bodenlinie [D]; ao, Kaudaler Winkel zwischen M. solearis der Ph. distalis und der Bodenlinie [C]; ap, Kaudaler Winkel zwischen dorsalem Kortex und M. solearis der Ph. distalis [C]; aq, Linearer Abstand zwischen der Spitze der Ph. distalis und $\operatorname{dem}$ Abrollpunkt des Hufs [A]; ar, Winkel zwischen M. coronalis und der Bodenlinie in lateraler Ansicht [D]; as, Winkel zwischen Planum cutaneum und F. flexoria der Ph. distalis im latereomedialem Strahlengang [C]; at, Winkel zwischen Planum cutaneum der Ph. distalis und der Bodenlinie im lateromedialen Strahlengang [C]; au, Winkel zwischen F. flexoria der Ph. distalis und der Bodenlinie im lateromedialen Strahlengang [C]; av, Winkel zwischen einer Linie parallel zur Trochlea phalangis mediae und einer Linie parallel zur F. articularis phalangis distalis [B]; aw, Winkel zwischen der Längsachse der Ph. media und einer Linie durch die Spitze der Ph. distalis und der Mitte der Art. interphalangea distalis [C]; ax, Winkel zwischen der proximodistalen Achse des Os sesamoideum distale und der Bodenlinie [C]; ay, Lateromediale Symmetrie: ay ${ }_{1}$, Winkel zwischen der distalen Kante der Ph. distalis und der Bodenlinie in dorsopalmarer Ansicht [B]; ay ${ }_{2}$. Winkel zwischen F. articularis der Ph. distalis und der Bodenlinie in dorsopalmarer Ansicht [B]; ay ${ }_{3^{\prime}}$ Winkel zwischen der Linie durch die distalen Kanten der Foramen soleare laterale et mediale der Ph. distalis und der Bodenlinie in dorsopalmarer Ansicht [B]; ay ${ }_{4}$. Winkel zwischen der Linie parallel zu M. coronalis und der Bodenlinie in dorsaler Ansicht [E]; az, Umfang des M. coronalis [F].

using 16 different terms. Interestingly, some authors preferred various terms for the same measurement in their subsequent publications. For example in (2) the measurement c (Fig. 3D) was called "Length of the ground bearing surface", whereas three years later the term "Foot length" was used (26). There were also discrepancies in the nomenclature of the same measurement in one handbook. In different chapters of "Adams \& Stashaks Lameness in Horses" (77) the terms "angle between the third phalanx and the ground" (Baxter et al. 2011), "solar angle" (Farstvedt 2011) and "palmar angle of distal phalanx" (O'Grady 2011) were used for the measurement ao (Fig. 3C). In one case the same term was used for different measures: "toe length" for the measure f (Fig. 3D) $(2,11,15,24,26$, $38,41,48,58,59,64,74,75,78$ ) and also for aq (Fig. 3A) (26). A simplified list of all the English and German terms used for those hoof measurements with the most inconsistent terminology is given in Table 2. Positive examples for a constant nomenclature of a frequently used dimension were measurement n (Fig. 3D), which was called heel length in all 12 papers in which it was mentioned $(13,19,21,41,43,51,57,58,59$, $64,75,78)$, and the angle am (Fig. 3D) with 22 entries $(2,13$, $19-21,26,29,35,38,48,51,53,57,58,55,64,70,72$, $74,75,77,78$ ) and only three used terms (heel angle, angle of the heel, palmar heel angle).

In German publications, including the reviews, all terms were used only once in 14 out of the 19 measurements (Fig. 3; $b_{1-3}, i_{1}, m, n, q$, af, am, ao, at, av, ay, three not depicted). Only in five cases were the terms for one measurement used more than once. The term "Rehestrecke" for the measurement a (Fig. 3A), "Zehenlänge" for f (Fig. 3D), and "Hufbeinrotation" for ag (Fig. 3C) were used in two publications each (43 and 79,32 and 43,18 and 79 , respectively) whereas "Hufbeinwinkel" for ah (Fig. 3C) and "Hufwinkel" for an (Fig. 3D) were used in three publications $(18,43,79)$.

\section{Definition of measures}

Definitions of the measurements in English publications are given uniformly either as a descriptive text in 10 out of 79 publications $(2,7,8,12,14,15,17,18,68,73)$, using an appropri- ate figure in 12 out of 79 publications $(4,23,25,30,44,45$, $47,49,53,55,56,76)$ or text combined with figure in 11 out of $79(9,10,16,28,39,54,60,61,69,71,79)$. In some papers, none of the measurements used were defined $(3,6,20$, $24,31,33,34,48)$. In the remaining 38 publications, a varied use of graphical and written definitions of measurements, as well as undefined terms, were recorded. In 6 publications, measures were defined but not given a specific term $(1,7,8$, 70, 77, 78).

In German publications, every mentioned measurement was defined, either in words, in a figure or both, with the exception of one measure (Fig. $3 A ; i 1$ ) in a single publication (32).

\section{Anatomical and language correctness}

Terms for position and direction (e.g. lateral/medial, proximal/ distal, palmar/plantar) based on the NAV (2017), as reference work for the standard vocabulary in veterinary anatomy were used in the definitions for 86 out of 110 hoof measurements with written definitions. Latin terms (NAV based) for anatomical structures were used in only 4 publications $(18,43,45$, 73), all of them in definitions in German.

The term "toe", in German "Zehe", was used by several authors (i.a. 11, 15, 29, 64, 78) to designate Pars dorsalis of the hoof capsule or even only its dorsodistal tip. The anatomical toe (digitus) is a body part containing Phalanx proximalis, Phalanx media and Phalanx distalis as skeletal structures and surrounding tissues including skin and its derivatives. In the publications analysed for this study, the term sole was often used for the total area of the hoof which is in contact with the ground, as in "sole length" (56) for the distance c (Fig. 3D), "sole width" $(22,64)$ for the distance $d$ (Fig. 3F) as well as "medial/lateral sole width" $(2,41,58)$ for distance $d_{\text {lat/med }}$ (Fig. 3F), including Margo solearis of Pars dorsalis, Pars lateralis and Pars mobilis lateralis as well as Cuneus ungulae and Torus corneus.

For terms derived from the anatomical structure sole (Solea), the term "solar", meaning "of or from the sun" (Cambridge dictionary, 2019), instead of "solear" was used in 22 publi- 
cations $(2,6,9,10,13,15,16,19,22,29,35,39,44,49$, $54,58,59,61,63,65,74,77)$.

\section{Discussion}

Sources

For this study, the database Scopus ${ }^{\circledR}$ was searched systematically. Scopus ${ }^{\circledR}$ was chosen because, apart from medi- cal journals, it includes a range of scientific journals that are not primarily linked with medicine and therefore not included in the medical standard database MEDLINE ${ }^{\circledR}$. Since the standard for a systematic literature review is 1-5 databases (Pati and Lorusso 2018), we attempted an overview search on a second database, PubMed ${ }^{\circledR}$, using the same search string. This search provided fewer results (not shown), but they were not substantially different. Therefore, Scopus ${ }^{\circledR}$ seemed appropriate as a primary source.

Table 2 Inconsistent terminology in equine hoof biometry: Example of eleven frequently but inconsistently used measurement terms in publications from January, 1 15t, 2010 to February, $21^{\text {st }}$, 2019. Superscript numbers refer to references listed in Table 1. | Uneinheitliche Terminologie der Maße am Pferdehuf: Beispiel von elf häufig verwendeten, aber unterschiedlich benannten Maßen aus Publikationen zwischen dem 01.01.2010 und dem 21.02.2019. Hochgestellte Zahlen verweisen auf die Literaturangaben in Tabelle 1.

Measure English term German term

Founder distance 233542434753606271 , Distal displacement' ${ }^{6}$, Extensor process (-/to) coronary band distance $^{975}$, Distal displacement of the distal phalanx ${ }^{16}$, Distance between the dorsal coronary band

a and the apex of the extensor process ${ }^{23}$, Coronet-extensor distance ${ }^{26}$, Coronary extensor distance ${ }^{35}$, Coronary band (:/to) extensor process distance ${ }^{39} 42$, Coronary band to extensor process ${ }^{41}$, Coronary band $^{72}$, Distal displacement of the distal phalanx/Sinking ${ }^{78}$

Wall thickness ${ }^{50236670}$, Thickness of the dorsal hoof wall ${ }^{63}$, Horn-lamellar zone width975, Integument depth of the dorsal aspect of the foot ${ }^{1671}$, Hoof wall thickness ${ }^{2675}$, Dorsal hoof width ${ }^{35}$, Dorsal hoof wall thickness ${ }^{39} 4346$, Dorsal horn laminar zone width ${ }^{40}$, Dorsal wall thickness ${ }^{41} 58$, P3 to dorsal hoof wall ${ }^{53}$, Hoof P3 distance ${ }^{54} 60$, HP distance ${ }^{62}$, Hoof wall distal phalanx distance ${ }^{67}$, Horn lamellar zone $^{72}$, Distance between the dorsal surface of the hoof capsule and the parietal surface of the distal phalanx ${ }^{77}$

Length of ground bearing surface ${ }^{2}$, Weightbearing length (of the foot) ${ }^{1321415874}$, Hoof solar length ${ }^{15}$, Support length ${ }^{19}$, Length at the ground surface ${ }^{20}$, Solar length ${ }^{2274}$, Foot length ${ }^{26} 47606675$, Hoof length ${ }^{27} 485775$, Distal phalanx length ${ }^{29}$, Length of the distal surface ${ }^{38}$, Sagittal length ${ }^{51}$, Sole length ${ }^{56}$, Weight bearing length lateral ${ }^{63}$, Length of the hoof ${ }^{77}$, Length of the hoof capsule ${ }^{78}$

Hoof width 1527525775 , Lateromedial width ${ }^{17}$, Width at the ground surface ${ }^{20}$, Sole width ${ }^{22} 64$, Foot width 26476066 , Width of the distal surface ${ }^{38}$, Bearing border width ${ }^{44}$, Width of the hoof ${ }^{4877}$, Solar width ${ }^{5974}$, Weight bearing length dorsal ${ }^{63}$, Width of the hoof capsule ${ }^{78}$

Distance between the dorsal, distal margin of the distal phalanx and the ground ${ }^{6}$, Thickness of the

$i_{1+2} \quad$ sole $^{6}$, Sole depth ${ }^{14} 233540417072$, Sole depth + cup depth $^{26}$, Sole thickness ${ }^{53} 62$ (depth), P3 bottom ${ }^{54}$, Dorsal/Palmar sole depth ${ }^{58}$, Tip of P3 to ground ${ }^{60}$, Sole thickness depth ${ }^{62}$

Sole depth at the tip pf P 3975 , Sole depth 26353977 , Sole horn thickness ${ }^{32}$, Lateral/Medial/Sagittal sole thickness ${ }^{42}$, Sole thickness ${ }^{43} 47$

Rotation of the distal phalanx ${ }^{2}$, Dorsal capsular rotation ${ }^{6}$, Angular deviation between the dorsal ag aspect of the DP (distal phalanx) and dorsum (dorsal aspect) of the hoof wall ${ }^{1678}$, Distal phalanx rotation ${ }^{26}$, Degree of Rotation ${ }^{39}$, Rotation angle ${ }^{62}$, Capsular rotation ${ }^{77}$

Distal phalanx axis ${ }^{26}$, Angle of the dorsal aspect of the distal phalanx to the horizontal ${ }^{13}$, Dorsal ah angle of the distal phalanx ${ }^{16}$, Distal phalanx angle 264347 , Dorsal angle of P3 ${ }^{41}$, Dorsal angle of distal phalan $x^{58}$, P3 angle ${ }^{60}$, Dorsal distal phalanx angle of P3 $3^{71}$

Hoof axis ${ }^{26}$, Angle between the dorsal hoof wall and the ground surface ${ }^{2}$, Hoof angle 34911273441 4347485360717275 , Dorsal hoof wall angle 91316212326273536375155576378 , Toe angle 1920242526$) 293341$ 58596472747778 , Dorsal hoof angle 24275362 , Hoof wall angle 26 , Hoof-ground angle ${ }^{28}$, Angle of the toe $^{30}$, Dorsal angle ${ }^{52}$, Dorsal wall angle of the hoo ${ }^{68}$

Palmar angle (of P3/distal phalanx/third phalanx) 29202326404143525862727775 , Angle of the solar surface of the distal phalanx relative to the ground ${ }^{6}$, Angle of the solar border of the distal phalanx to the horizontal ${ }^{13}$, Angle of solar aspect of the distal phalanx ${ }^{16}$, P3 solar angle ${ }^{19}$, Angle between the solar margin of the distal phalanx and the ground surface 23 , Solar angle 233947 , Angle between solar margin of distal phalanx and ground ${ }^{35}$, Angle between Margo solearis of the distal phalanx and the ground ${ }^{45}$, Angle between the solar margin of the distal phalanx and the ground 495065 , P3 palmar $a$ angle ${ }^{53}$, P3-bottom angle 5460 , Distal phalanx angle ${ }^{61}$, Angle of the distal phalanx and the ground ${ }^{68}$, Plantar angle of the distal phalan $x^{69}$, Angle between the solar aspect of the distal phalanx and the ground $^{71}$, Angle between the third phalanx and the ground, Solar angle $\mathrm{e}^{77}$

Lateral-medial balance ${ }^{4}$, Mediolateral rotation or asymmetric distal displacement ${ }^{6}$, Medio-lateral balance $^{112675} 78$, Mediolateral angle ${ }^{28}$, Mediolateral symmetry 35 , Angle between Margo solearis of

ay $_{1-4} \quad$ the distal phalanx and the ground ${ }^{45}$, Angle between the solear margin of the distal phalanx and the ground $^{495065}$. Lateromedial balance ${ }^{61}$, Asymmetric displacement ${ }^{77}$, Medial-to-lateral hoof balance ${ }^{78}$
Rehestrecke $^{43} 79$

Hufbeinsenkung ${ }^{18}$, Wanddicke ${ }^{43}$, Dicke der dorsalen Hufwand ${ }^{73}$, Parallelität zwischen dorsaler Hufbeinfläche und Vorderwand ${ }^{79}$
Palmar-/Plantarwinkel ${ }^{43}$, Winkel zwischen Margo solearis und Boden $^{45}$, Palmarer Winkel ${ }^{79}$ 
Books have been included in this search because standard handbooks usually provide an appropriate nomenclature for scientists in the field. We decided to select handbooks based on recommendations of veterinarian orthopaedists. We are aware that this choice may be biased by personal preference. While the significance of "Adam \& Stashaks Lameness in Horses", with over 1400 citations by publications listed in Scopus ${ }^{\circledR}$, is not to be doubted, other books might be preferred by other specialists. The five chosen books cover English and German language as well as literature relevant for clinicians and farriers.

The timeframe of the last ten years was arbitrarily chosen for this study with the aim to map the recent discussion in the field. However, a number of frequently cited papers addressing hoof measurements and nomenclature were not included in the chosen timeframe (Cripps and Eustace 1999, Kummer et al. 2004, Rocha et al. 2004). Moreover, it has to be tak- en into account that equine orthopedia and pedology date back to ancient times, consequently hoof nomenclature has developed and diversified over centuries in equine medicine and farriery.

The classification between original and review group within the included publications was difficult, as some papers did not meet the standard categories of the journals. An attempt was made to examine each paper for the originality of the measurement data and to assign it to the groups accordingly, as described in Material and Methods. Two papers (Floyd 2010, Eggleston 2012) defined by the editors as clinical technique and review, respectively, were therefore classified as original papers for the purpose of our study.

The number of measurements per original paper ranged widely between one and 32. Papers with a high number of measurements usually dealt exclusively with the hoof (Hamp-

Table 3 Suggested terms for the most frequently used measurements in English and German with reference to the corresponding measure in Figure 3. Empfohlene Begriffe für die meistverwendeten Maße in Englisch und Deutsch mit Hinweisen zu den Maßen in Abbildung 3.

\begin{tabular}{|c|c|c|c|}
\hline Measure & $\begin{array}{l}\text { Suggested term } \\
\text { English }\end{array}$ & $\begin{array}{l}\text { Suggested term } \\
\text { German }\end{array}$ & $\begin{array}{l}\text { Terms used most frequently } \\
\text { Englisch, German }\end{array}$ \\
\hline a & Founder distance & Rehestrecke & $\begin{array}{l}\text { Founder distance } \\
\text { Rehestrecke }\end{array}$ \\
\hline$b$ & Dorsal hoof wall thickness & Dicke der dorsalen Hufwand & $\begin{array}{l}\text { Dorsal hoof wall thickness } \\
\text { Hufbeinsenkung\#, Wanddicke\#, Dicke der dorsalen Hufwand\#, } \\
\text { Parallelität zwischen dorsaler Hufbeinfläche und Vorderwand\# }\end{array}$ \\
\hline c & Weightbearing length & Länge der Fußungsfläche** & $\begin{array}{l}\text { Weightbearing length\#, Foot length\# } \\
/\end{array}$ \\
\hline$d$ & Hoof width & Hufweite** & Hoof width \\
\hline$f$ & Dorsal hoof wall length* & Länge der dorsalen Hufwand** & $\begin{array}{l}\text { Toe length } \\
\text { Zehenlänge }\end{array}$ \\
\hline $\mathrm{i}_{1}+\mathrm{i}_{2}$ & Sole depth & Sohlentiefe** & $\begin{array}{l}\text { Sole depth } \\
\text { / }\end{array}$ \\
\hline $\mathrm{i}_{1}$ & Sole horn thickness* & Sohlenhorndicke & $\begin{array}{l}\text { Sole depth } \\
\text { Sohlenhorndicke }\end{array}$ \\
\hline$n$ & Heel length & Trachtenlänge & $\begin{array}{l}\text { Heel length } \\
\text { Trachtenlänge }\end{array}$ \\
\hline q & Heel height & Trachtenhöhe** & $\begin{array}{l}\text { Heel height } \\
\text { Palmare/plantare Kronsaumhöhe }\end{array}$ \\
\hline ag & Distal phalanx rotation* & Hufbeinrotation & $\begin{array}{l}\text { Angular deviation between the dorsal aspect of the distal phalanx } \\
\text { and dorsum (dorsal aspect) of the hoof wall } \\
\text { Hufbeinrotation }\end{array}$ \\
\hline ah & Distal phalanx angle & Hufbeinwinkel & $\begin{array}{l}\text { Distal phalanx angle } \\
\text { Hufbeinwinkel }\end{array}$ \\
\hline am & Heel angle & Trachtenwinkel & $\begin{array}{l}\text { Heel angle } \\
\text { Trachtenwinkel }\end{array}$ \\
\hline an & Dorsal hoof wall angle* & Hufwinkel & $\begin{array}{l}\text { Toe angle } \\
\text { Hufwinkel }\end{array}$ \\
\hline ao & Palmar/Plantar angle & Palmar-/Plantarwinkel & $\begin{array}{l}\text { Palmar angle } \\
\text { Palmar-/Plantarwinkel\#, Winkel zwischen Margo solearis und } \\
\text { Boden\#, palmarer Winkel\# }\end{array}$ \\
\hline ay & Mediolateral symmetry* & Mediolaterale Symmetrie ${ }^{* *}$ & $\begin{array}{l}\text { Medial-lateral balance } \\
\text { Mediolaterale Verkippung/Imbalance }\end{array}$ \\
\hline
\end{tabular}

\# terms used equally often, ${ }^{*}$ term from publications between January, $1^{\text {st }}, 2010$ and February, $21^{\text {st }}, 2019$, not most often used, ${ }^{* *}$ new term | \# Begriffe die gleich oft verwendet wurden, *Begriff aus der Literatur zwischen dem 01.01.2010 und dem 21.02.2019, nicht am meisten verwendet **, neuer Begriff 
son et al. 2010, Dyson et al. 2011, Holroyd et al. 2013, Thieme et al. 2015a, de Zani et al. 2016, Faramarzi et al. 2017), whereas papers for studies with few hoof measurements included a variety of other dimensions, as for example the relative head size (van Heel et al. 2010), the metacarpophalangeal joint angulation (Hagen et al. 2018) or the length of Phalanx media (Walliser et al. 2018).

\section{Inconsistencies of nomenclature}

The lack of a consistent nomenclature, at least for the most commonly used hoof measures, decreases both readability and comparability of publications on this topic. Particularly, nomenclature inconsistencies within standard handbooks (Baxter 2011) represent a major problem, as these publications are used as reference works for individual researchers and clinicians. The inconsistencies probably originate from the fact that the individual chapters were written by different authors (Baxter et al. 2011 1, Farstvedt 201 1, O'Grady 2011) and the editor did not choose to standardise the terms. Various use of terms could also be seen in different publications of the same author (Hampson et al. 2010, 2013), who may have deliberately changed the term but gave no reason for it. The lack of a standard nomenclature leads also to homonyms, as seen for the term "toe length". Interestingly the double use of one term (Fig. 3A, D; f, aq) was recorded in the same publication (Hampson et al. 2013a).

In contrast, there seems to be a general agreement regarding the terminology for structures of the heel, since the terms describing its biometry are very constant (Fig. 3D; n, am).

Of the terms for measurements given in the German language, only 5 of 19 terms were used twice or more. However, the number of German publications analysed for this study was too small for a definite conclusion regarding the consistency of terminology.

\section{Definition of measures}

For the sake of repeatability and comparability of research, definitions of recorded measures should be as unambiguous as possible. A description either solely by words or exclusively by a figure seems insufficient. For the purpose of this study, it was very difficult to understand the definitions of the measurements based on only one kind of description or to assign them correctly at all. Interestingly, almost all terms in German publications were defined in detail, with only one exception ( $i_{1}$, Fig. 3A, Patan-Zugai et al. 2013). In English publications, approximately the same number of authors have given the definitions either in written form or with a figure (10 and 12 out of 79 , respectively). Unfortunately, only 11 out of 79 authors decided to define terms in both ways. In about half of the publications (38 out of 79), authors did not define their terms in a constant form, but used text, figures or no definition at all. The risk for misunderstandings and even mistakes can be expected to be higher when using only one way to demonstrate the measurement: Floyd and Mansmann (2007) termed a measurement "hoof width" although the halfwidth of the hoof was shown in the according figure. In de Souza et al. (2017) the width of the coronary band in dorsal view was demonstrated in a figure although the measurement was called "coronary band perimeter". The term perimeter, i.e. the distance around a given two-dimensional object, should be a circumferential measure and was probably meant in this case, based on the measured values for a foal hoof of approximately $19-26 \mathrm{~cm}$.

In 8 out of 79 publications, no definitions of measurements and no reference to definitions in other sources were given. In these cases, repetition of these studies would be very difficult or even impossible.

\section{Anatomical and language correctness}

For the description of the hoof and its structures, a consolidated anatomical Latin nomenclature as fixed in the NAV (2017) is available. Alternatively settled English or German nomenclature might be employed. In only a few publications, all of them German, did the authors use the hoof structures' Latin terms to describe the measurements (Hertsch and Teschner 2011 , Hagen et al. 2015, Thieme et al. 2015b, Walliser et al. 2018). This may be based on the fact that German terms for hoof structures are perceived as colloquial, whereas English terms are often very similar to the Latin ones (e.g. Latin: Phalanx distalis, German: Hufbein, English: distal phalanx). Irrespective of the language, it is important to use standard vocabulary for the definition of measurements, especially when there is no standard set of terms to rely on. Interestingly, in neither German nor English is the hoof measurement terminology completely consistent with the canonised anatomical nomenclature NAV (2017). An example is the word toe/Zehe. It is often used for the Pars dorsalis of the cornified hoof capsule as in "toe length" (Hampson et al. 2010, Stachurska et al. 2011, Lewis et al. 2014), "toe height" (Holroyd et al. 2013) or "Zehenlänge" (Patan-Zugai et al. 2013, Thieme et al. 2015b). In the anatomical sense, the toe length would be the distance between Articulatio metacarpo-(metatarso-)phalangea and the dorsodistal tip of the hoof capsule.

Another example is the word "solar" (real meaning of or from the sun), used in English nomenclature to describe the hoof sole (Solea) and related structures. The term was used in 22 out of 79 publications in names for a measurement e.g. "solar length" (Fig. 3D; c) (Parés i Casanova and Oosterlinck 2012, Faramarzi et al. 2018) and also in definitions like "Angle between the solar surface of the distal phalanx and the ground" (Fig. 3C; ao) (de Zani et al. 2016). The use of the term solar instead of solear does not seem to be dependent on whether or not the authors are native speakers/working in countries where English is the main language (Hampson et al. 2010, Collins et al. 2011, Hagen et al. 2016).

It has to be taken into account that measurements defined by the term sole do not include the anatomical sole segment only (Fig. 3D, F; c, d, $d_{\text {lat/med }}$ ) but the complete so-called Facies solearis. NAV (2017) defines Facies solearis as a composite of all structures visible on the ground surface including Facies contactus with Margo solearis, Zona alba, the peripheral zone of the sole and Crura cunei, and Facies fornicis.

However, these "incorrect" terms are well established in farriery and equine medicine. If they are to be used in an ana- 
tomical context, it might be advisable to define them in the respective publication in detail, preferably both in written form and in figures, in order to prevent misunderstandings.

\section{Conclusion}

When reviewing literature or citing papers on hoof biometry, one should be aware of the fact that different terms might be used for the same item or that the same term might signify different measures in different publications. Consistent use of terminology, at least in the frame of one working group, is strongly recommended. A suggestion for the terminology of 15 commonly used measurements in English and German is given in Table 3. It is an attempt to ensure maximal anatomical correctness while taking well-established terms into account. Considering the fact that no standardized nomenclature for hoof measurements exists, in manuscripts dealing with hoof biometry, all measures should be described and defined in great detail. For this purpose, orientation towards the well defined veterinary anatomical nomenclature (NAV) might be helpful.

\section{Acknowledgement}

We would like to thank Dr. J. Hagen and Prof. Chr. Mülling (Institute of Anatomy, Histology and Embryology, Faculty of Veterinary Medicine, Universität Leipzig, Germany) for their help with the identification of relevant monographies. Radiographs for Figure 3 were provided by the Clinical Unit of Diagnostic Imaging, Department/University Clinic for Companion Animals and Horses, University of Veterinary Medicine, Vienna.

\section{Funding}

This study was supported by the Hochschuljubiläumsstiftung der Stadt Wien (Project No. 291437/2019).

\section{References}

Amitrano F. N., Gutierrez-Nibeyro S. D., Schaeffer D. J. (2016) Effect of hoof boots and toe-extension shoes on the forelimb kinetics of horses during walking. Am. J. Vet. Res. 77, 527-533; DOI 10.2460/ajvr.77.5.527

Baxter G. M. (2011) Adams \& Stashaks's Lameness in Horses, Wiley-Blackwell, West Sussex, Edition 6

Baxter G. M., Stashak T. S., Belknap J. K., Parks A. (2011) Lameness in the extremities, The Foot, In: Baxter G. M., Adams \& Stashaks's Lameness in Horses, Wiley-Blackwell, West Sussex, Edition 6, 475-558

Bellenzani M. C. R., Merritt J. S., Clarke S., Davies H. M. S. (2012) Investigation of forelimb hoof wall strains and hoof shape in unshod horses exercised on a treadmill at various speeds and gaits. Am. J. Vet. Res. 73, 1735-1741; DOI 10.2460/ajvr.73.11.1735

Bhatnagar A. S., Pleasant R. S., Dascanio J. J., Lewis S. R., Grey A., Schroeder O. E., Doyle K., Hall J., Splan R. K. (2010) Hoof conformation and palmar process fractures of the distal phalanx in warmblood foals. J. Equine Vet. Sci. 30, 349-355; DOI 10.1016/j.jevs.2010.05.004

Bras R. J., Redden R. (2018) Understanding the Basic Principles of Podiatry. Vet. Clin. N. Am. - Equine 34, 391-407; DOI 10.1016/i. cveq.2018.04.015
Caldwell M. N., Allan L. A., Pinchbeck G. L., Clegg P. D., Kissick K. E., Milner P. I. (2016) A test of the universal applicability of a commonly used principle of hoof balance. Vet. J. 207, 169-176; DOI 10.1016/i.tvil.2015.10.003

Cambridge Dictionary (2019), Entry "solar", retrieved 17/12, 2019 from https://dictionary.cambridge.org/dictionary/english/solar

Clayton H. M., Gray S., Kaiser L. J., Bowker R. M. (2011) Effects of barefoot trimming on hoof morphology. Aust. Vet. J. 89, 305311 ; DOI 10.1111/j.1751-0813.2011.00806.x

Colborne G. R., Routh J. E., Weir K. R., McKendry J. E., Busschers E. (2016) Associations between hoof shape and the position of the frontal plane ground reaction force vector in walking horses. New Zeal. Vet. J. 64, 76-81; DOI 10.1080/00480169.2015.1068138

Collins S. N., Dyson S. J., Murray R. C., Burden F., Trawford A. (2011) Radiological anatomy of the donkey's foot: Objective characterisation of the normal and laminitic donkey foot. Equine Vet. J. 43, 478-486; DOI 10.1111/i.2042-3306.2010.00312.x

Cripps P. J., Eustace R. A. (1999) Radiological measurements from the feet of normal horses with relevance to laminitis. Equine Vet. J. 31, 427-432; DOI 10.1111/i.2042-3306.1999.tb03844.x

Cruz C. D., Thomason J. J., Faramarzi B., Bignell W. W., Sears W., Dobson H., Konyer N. B. (2006) Changes in shape of the Standardbred distal phalanx and hoof capsule in response to exercise. Equine Comp. Exerc. Physiol. 3, 199-208; DOI 10.1017/ S1478061506617258

Cust A., Anderson G., Whitton R., Davies H. (2013) Hoof conformation and performance in the racing Thoroughbred in Macau, Aust. Vet. J. 91 (3), 108-112; DOI 10.1111/avj.12012

Decurnex V., Anderson G. A., Davies H. M. S. (2009) Influence of different exercise regimes on the proximal hoof circumference in young Thoroughbred horses. Equine Vet. J. 41, 233-236; DOI 10.2746/042516409X393220

de Souza J. R. M., Pfeifer J. P. H., Folle V. A., Lau L. C., Schuster A. B. G., Segabinazzi L. G. T. M., Pimentel A. M. H., Martins C. F. (2017) Morphometric changes in the hoof capsule of Criollo foals from birth to weaning. Cienc. Rural 47, 1-5; 1DOI 0.1590/01038478 cr20160945

de Zani D., Polidori C., di Giancamillo M., Zani D. D. (2016) Correlation of radiographic measurements of structures of the equine foot with lesions detected on magnetic resonance imaging. Equine Vet. J. 48, 165-171; DOI 10.1111/evj.12411

Dijkstra A. M., Sinnige T. C., Rogers C. W., Gee E. K., Bolwell C. F. (2016) Preliminary examination of farriery and hoof care practices and owner-reported injuries in sport horses in New Zealand. J. Equine Vet. Sci. 46, 82-88; DOI 10.1016/j.jevs.2016.07.011

Drumond B., Guimaraes Ginelli A. M., Faleiros R. R., de Magalhaes J. F., Coelhos C. S. (2016) Hoof capsule distortion and radiographic measurements of the front feet in Mangalarga Marchador horses subjected to athletic training. Pferdeheilkunde 32, 110-118; DOI 10.21836/PEM20160203

Dyson S. J., Tranquille C. A., Collins S. N., Parkin T. D. H., Murray $R$. C. (2011a) An investigation of the relationships between angles and shapes of the hoof capsule and the distal phalanx. Equine Vet. J. 43, 295-301; DOI 10.1111/i.20423306.2010.00162.x

Dyson S. J., Tranquille C. A., Collins S. N., Parkin T. D. H., Murray R. C. (2011b) External characteristics of the lateral aspect of the hoof differ between non-lame and lame horses, Vet. J. 190 (3), 364-371; DOI 10.1016/i.tvil.2010.11.015

Eggleston R. B. (2012) Equine imaging: The framework for applying therapeutic farriery, Vet. Clin. N. Am. - Equine 28 (2), 293-312; DOI 10.1016/i.cveq.2012.05.001

El-Shafaey E. A., Salem M. G., Mosbah E., Zaghloul A. (2017) Morphometric evaluation of relevant radiographic parameters of the forefeet of clinically normal donkeys (Equus asinus). J. Hell. Vet. Med. Soc. 68, 467-478; DOI 10.12681/jhvms. 15543

Eliashar E. (2012) The Biomechanics of the equine foot as it pertains to farriery. Vet. Clin. N. Am. - Equine 28, 283-291; DOI 10.1016/i.cveq.2012.06.001 
Eustace R. A. (2010) Clinical presentation, diagnosis, and prognosis of chronic laminitis in Europe. Vet. Clin. N. Am. - Equine 26, 391-405; DOI 10.1016/i.cveq.2010.06.005

Faramarzi B., Mcmicking H., Halland S., Kaneps A., Dobson H. (2015) Incidence of palmar process fractures of the distal phalanx and association with front hoof conformation in foals. Equine Vet. J. 47,675-679; DOI 10.1111/evj.12375

Faramarzi B., Salinger A., Kaneps A., Nout-Lomas Y., Greene H., Dong F. (2017) Quantitative analysis and development of the fore feet of arabian foals from birth to 1 year of age. Vet. Comp. Orthopaed. 30, 403-412; DOI 10.3415/VCOT-16-11-0158

Faramarzi B., Kepler A., Dong F., Dobson H. (2018) Morphovolumetric analysis of the hoof in Standardbred horses. J. Equine Vet. Sci. 71, 40-45; DOI 10.1016/i.jevs.2018.08.012

FarstvedtE. G. (2011) Occupation-related lameness conditions, show/ pleasure horses, In: Baxter G. M., Adams \& Stashaks's Lameness in Horses, Wiley-Blackwell, West Sussex, Edition 6, 1062-1067

Floyd A. E. (2010) Use of a grading system to facilitate treatment and prognosis in horses with negative palmar angle syndrome (heel collapse): 107 cases. J. Equine Vet. Sci. 30, 666-675; DOI 10.1016/i.jevs.2010.10.002

Floyd A. E., Mansmann R. A. (2007) Equine Podiatry, Elsevier Saunders, Missouri, Edition 1

Gordon S., Rogers C., Weston J., Bolwell C., Doloonjin O. (2013) The forelimb and hoof conformation in a population of mongolian horses. J. Equine Vet. Sci. 33, 90-94; DOI 10.1016/i. jevs.2012.05.058

Goulet C., Olive J., Rossier Y., Beauchamp G. (2015) Radiographic and anatomic characteristics of dorsal hoof wall layers in nonlaminitic horses. Vet. Radiol. Ultrasoun. 56, 589-594; DOI 10.1111/vru.12280

Grundmann I. N. M., Drost W. T., Zekas L. J., Belknap J. K., Garabed R. B., Weisbrode S. E., Parks A. H., Knopp M. V., Maierl J. (2015) Quantitative assessment of the equine hoof using digital radiography and magnetic resonance imaging. Equine Vet. J. 47, 542-547; DOI 10.1111/evj.12340

Hagen J., Hüppler M., Häfner F. S., Marion S., Mäder D. (2015) Untersuchung des Einflusses unterschiedlicher Bodenbeschaffenheiten auf die Ausrichtung der distalen Zehenknochen des Pferdes, Pferdeheilkunde 31 (6), 578-586; DOI 10.21836/ PEM20150605

Hagen J., Hüppler M., Häfner F., Geiger S., Mäder D. (2016) Modifying horseshoes in the mediolateral plane: Effects of side wedge, wide branch, and unilateral roller shoes on the phalangeal alignment, pressure forces, and the footing pattern, J. Equine Vet. Sci. 37, 77-85; DOI 10.1016/j.jevs.2015.12.001

Hagen J., Hüppler M., Geiger S. M., Mäder D., Häfner F. S. (2017) Modifying the height of horseshoes: Effects of wedge shoes, studs, and rocker shoes on the phalangeal alignment, pressure distribution, and hoof-ground contact during motion. J. Equine Vet. Sci. 53, 8-18; DOI 10.1016/i.jevs.2017.01.014

Hagen J., Kojah K., Geiger S. M. (2018) Correlations between the equine metacarpophalangeal joint angulation and toe conformation in statics. Open Vet. J. 8, 2226-4485, DOI 10.4314/ovj.v8i1.15

Hampson B. A., Ramsey G., Macintosh A. M. H., Mills P. C., de Laat M. A., Pollitt C. C. (2010) Morphometry and abnormalities of the feet of Kaimanawa feral horses in New Zealand. Aust. Vet. J. 88, 124-131; DOI 10.1111/j.1751-0813.2010.00554.x

Hampson B. A., Connelley A. D., de Laat M. A., Mills P. C., Pollitt C. C. (2011) Sole depth and weight-bearing characteristics of the palmar surface of the feet of feral horses and domestic Thoroughbreds. Am. J. Vet. Res. 72, 727-735; DOI 10.2460/ ajvr.72.6.727

Hampson B. A., de Laat M. A., Mills P. C., Pollitt C. C. (2013) The feral horse foot. Part A: Observational study of the effect of environment on the morphometrics of the feet of 100 Australian feral horses. Aust. Vet. J. 91 (1-2), 14-22; DOI 10.1111/avj.12017

Hertsch B., Teschner D. (2011) Das Hornwachstum bei der chronischen Hufrehe des Pferdes. Tierarztl. Prax. K. H. 39, 163-170; DOI 10.1055/s-0038-1624632
Holden-Douilly L., Pourcelot P., Desquilbet L., Falala S., CrevierDenoix N., Chateau H. (2013) Equine hoof slip distance during trot at training speed: Comparison between kinematic and accelerometric measurement techniques. Vet. J. 197, 198-204; DOI 10.1016/j.tvjl.2013.02.004

Holroyd K., Dixon J. J., Mair T., Bolas N., Bolt D. M., David F., Weller R. (2013) Variation in foot conformation in lame horses with different foot lesions. Vet. J. 195, 361-365; DOI 10.1016/i. tvjl.2012.07.012

Hüppler M., Häfner F., Geiger S., Mäder D., Hagen J. (2016) Modifying the surface of horseshoes: Effects of eggbar, heartbar, open toe, and wide toe shoes on the phalangeal alignment, pressure distribution, and the footing pattern. J. Equine Vet. Sci. 37, 86-97; 10.1016/j.jevs.2015.12.009

Jansová M., Ondoková L., Vychytil J., Kochová P., Witter K., Tonar Z. (2015) A finite element model of an equine hoof. J. Equine Vet. Sci. 35, 60-69; 10.1016/i.jevs.2014.11.008

Kane A. J., Stover S. M., Gardner I. A., Bock K. B., Case J. T., Johnson B. J., Anderson M. L., Barr B. C., Daft B. M., Kinde H., Larochelle D., Moore, J., Mysore J., Stoltz J., Woods L., Read D. H., Ardans A. A. (1998) Hoof size, shape, and balance as possible risk factors for catastrophic musculoskeletal injury of Thoroughbred racehorses. Am. J. Vet. Res. 59, 1545-1552

Karle A. S., Tank P. H., Vedpathak H. S., Mahida H. K., Shah R. G., Dhami M. A. (2010) Horseshoeing: An overview. Vet. World 3, 148-151

Kolstrung R., Stachurska A., Pięta M., Silmanowicz P., Ussing A. P. (2013) Hoof wall angulation in the horse (Equus caballus). Med. Weter. 69, 181-186

Kummer M., Lischer C., Ohlerth S., Vargas J., Auer J. (2004) Evalvation of a standardised radiographic technique of the equine hoof. Schweiz. Arch. Tierh. 146, 507-514; DOI 10.1024/0036$-7281.146 .11 .507$

Labens R., Redding W. R., Desai K. K., vom Orde K., Mansmann R. A., Blikslager A. T. (2013) Validation of a photogrammetric technique for computing equine hoof volume. Vet. J. 197, 625-630; DOI 10.1016/j.tvjl.2013.04.005

Labuschagne W., Rogers C. W., Gee E. K., Bolwell C. F. (2017) A cross-sectional survey of forelimb hoof conformation and the prevalence of flat feet in a cohort of thoroughbred racehorses in New Zealand. J. Equine Vet. Sci. 51, 1-7; DOI 10.1016/i. jevs.2016.11.013

Leśniak K., Williams J., Kuznik K., Douglas P. (2017) Does a 4-6 week shoeing interval promote optimal foot balance in the working equine? Animals 7, 29; DOI 10.3390/ani7040029

Lewis C., Nadeau J., Hoagland T., Darre M. (2014) Effect of season on travel patterns and hoof growth of domestic horses. J. Equine Vet. Sci. 34, 918-922; DOI 10.1016/i.jevs.2014.04.010

Litzke L.-F., Rau B. (2012) Der Huf, Enke Verlag in MVS Medizinverlage Stuttgart, GmbH \& Co. KG., Stuttgart, Edition 6

Mansmann R. A., James S., Blikslager A. T., vom Orde K. (2010) Long toes in the hind feet and pain in the gluteal region: An observational study of 77 horses. J. Equine Vet. Sci. 30, 720-726; DOI 10.1016/j.jevs.2010.11.007

Meira C. T., Curi R. A., Vasconcelos Silva J. A. II, Monteiro Corrêa M. J., Nunes de Oliveira H., Silveira da Mota M. D. (2013) Morphological and genomic differences between cutting and racing lines of Quarter Horses. J. Equine Vet. Sci. 33, 244-249; DOI 10.1016/j.jevs.2012.07.001

Moher D., Liberati A., Tetzlaff J., Altman D. G., Altman D., Antes G., the PRISMA Group (2009) Preferred reporting items for systematic reviews and meta-analyses: The PRISMA statement. Plos Med. 6, 1-6; DOI 10.1371/journal.pmed.1000097

Mullard J., Ireland J., Dyson S. (2018) Radiographic assessment of the ratio of the hoof wall distal phalanx distance to palmar length of the distal phalanx in 415 front feet of 279 horses. Equine Vet. Educ. 30, 1-9; DOI 10.1111/eve.13004

NAV (Nomina Anatomica Veterinaria) (2017) retrieved 19/1 1, 2019, from http://www.wava-amav.org/ 
O'Grady S. E. (2010) Farriery for chronic laminitis. Vet. Clin. N. Am. - Equine 26, 407-423; DOI 10.1016/i.cveq.2010.04.008

O'Grady S. E. (2011) Foot Care and Farriery, Farriery for common hoof problems, In: Baxter G. M., Adams \& Stashaks's Lameness in Horses, Wiley-Blackwell, West Sussex, Edition 6, 1199-1210

Parés i Casanova P. M. (2011) A nonlinear model for estimating hoof surface area in unshod meat-type horses. J. Equine Vet. Sci. 31, 379-382; DOI 10.1016/j.jevs.2011.03.020

Parés i Casanova P. M., Oosterlinck M. (2012) Hoof size and symmetry in young Catalan Pyrenean horses reared under semi-extensive conditions. J. Equine Vet. Sci. 32, 231-234; DOI 10.1016/j. jevs.201 1.08.020

Patan-Zugaj B., Herrmann C., Mülling C., Budras K. (2013) Zur Geschichte des Przewalskipferdes (Equus przewalskii) und morphologische Untersuchungen jahreszyklischer Veränderungen am Huf von Urwildpferden und wildlebenden Hauspferden. Pferdeheilkunde 29, 295-302; DOI 10.21836/PEM20130302

Pati D., Lorusso L. N. (2018) How to write a systematic review of the literature. Herd-Health. Env. Res. 11, 15-30; DOI $10.1177 / 1937586717747384$

Pauwels F. E., Rogers C. W., Wharton H., Flemming H., Wightman P. F., Green R. W. (2017) Radiographic measurements of hoof balance are significantly influenced by a horse's stance. Vet. Radiol. Ultrasoun. 58, 10-17; DOI 10.1111/vru.12443

Pezzanite L., Bass L., Kawcak C., Goodrich L., Moorman V. (2018) The relationship between sagittal hoof conformation and hindlimb lameness in the horse. Equine Vet. J. 50 (2018), 1-6; DOI 10.1111/evj.13050

Ramsey G. D., Hunter P. J., Nash M.P. (2011) The effect of hoof angle variations on dorsal lamellar load in the equine hoof. Equine Vet. J. 43, 536-542; DOI 10.1111/j.2042-3306.2010.00319.x

Reilly P. T. (2010a) In-shoe force measurements and hoof balance. J. Equine Vet. Sci. 30, 475-478; DOI 10.1016/i.jevs.2010.07.013

Reilly P. T. (2010b) Management of the dorsal hoof wall and its potential effects on the laminitic hoof. J. Equine Vet. Sci. 30, 513516; DOI 10.1016/j.jevs.2010.07.020

Ribeiro R. M., Mendes H. M. F., Valadares R. C., Paz C. F. R., De Paula A., De Oliveira L., Spadeto O., Faleiros R. R. (2017) A novel equine hoof lamellar tissue biopsy technique. J. Equine Vet. Sci. 49, 63-68; DOI 10.1016/i.jevs.2016.10.007

Rocha J. V., Lischer C. J., Kummer M., Hässig M., Aver J. A. (2004) Evaluating the measuring software package Metron-PX for morphometric description of equine hoof radiographs. J. Equine Vet. Sci. 24, 347-354; DOl 10.1016/j.jevs.2004.07.002

Ronchetti A., Day P., Weller R. (2011) Mediolateral hoof balance in relation to the handedness of apprentice farriers. Vet. Rec. 168, 48; DOI 10.1136/vr.c5993

Ross M., Dyson S. J. (2011) Lameness in the horse, Elsevier Saunders, Missouri, Edition 2

Sherlock C., Parks A. (2013) Radiographic and radiological assessment of laminitis. Equine Vet. Educ. 25, 524-535; DOI 10.1111/eve.12065

Simonato S. P., De Souza M. V., Diaz M. A. N., Frassy L. N., de Oliveira Pinto J. (2013) Aloe vera-based formula as emollient on horses' hooves. Rev. Ceres 60, 318-323; 10.1590/S0034737X2013000300003

Souza A. F., Kunz J. R., Laus R., Moreira M. A., Muller T. R., Fonteque J. H. (2016) Biometrics of hoof balance in equids. Arq. Bras. Med. Vet. Zoo. 68, 825-831, DOI 10.1590/1678-4162-8848

Stachurska A., Kolstrung R., Pięta M., Silmanowicz P. (201 1) Hoof size as related to body size in the horse (Equus caballus). Anim. Sci. Pap. Rep. 29, 213-222

Stashak T. S. (2010) Adam's Lahmheit bei Pferden, M. \& H. Schaper $\mathrm{GmbH}$, Hannover, Edition 4
Tanaka K., Hiraga A., Takahashi T., Kuwano A., Morrison S. E. (2015) Effects of aluminum hinged shoes on the structure of contracted feet in Thoroughbred yearlings. J. Equine Sci 26, 67-71; DOI 10.1294/jes.26.67

Taylor D., Sperandeo A., Schumacher J., Passler T., Wooldridge A., Bell R., Cooner A., Guidry L., Matz-Creel H., Ramey I., Ramey P. (2014) Clinical outcome of 14 obese, laminitic horses managed with the same rehabilitation protocol. J. Equine Vet. Sci. 34, 556564; DOI 10.1016/i.jevs.2013.08.052

Thieme K., Ehrle A., Lischer C. (2015a) Radiographic measurements of the hooves of normal ponies. Vet. J. 206, 332-337; DOI 10.1016/i.tvj|.2015.10.005

Thieme K., Ehrle A., Lischer C. (2015b) Morphometrische Messungen am Pferdehuf - eine Literaturübersicht. Pferdeheilkunde 31, 108-118, DOI 10.21836/PEM20150201

Tocci R., Sargentini C., Martini A., Andrenelli L., Pezzati A., Benvenuti D., Giorgetti A. (2017) Hoof quality of Anglo-Arabian and Haflinger horses. J. Vet. Res. (Poland) 61, 367-373; DOI 10.1515/ivetres-2017-0049

Tracey A., McClure S. R. (2018) Retrospective analysis of distal limb conformation and lameness in mature horses after desmotomy of the accessory ligament of the deep digital flexor tendon for management of a flexural deformity. Equine Vet. Educ. 30 , 53-56; DOI 10.1111/eve.12768

van Eps A. W. (2010) Acute laminitis: medical and supportive therapy. Vet. Clin. N. Am. - Equine 26, 103-114; DOI 10.1016/i. creq.2009.12.011

van Heel M. C. V., van Dierendonck M. C., Kroekenstoel A. M., Back W. (2010) Lateralised motor behaviour leads to increased unevenness in front feet and asymmetry in athletic performance in young mature Warmblood horses. Equine Vet. J. 42, 444-450; DOI 10.1111/i.2042-3306.2010.00064.x

Van Thielen B., Willekens I., Van der Schicht A., Pestieau P., Verhelle F., Goossens P., Decoster R., JacqmotO., Delperdange P., Busoni V., De Mol G., Buls N., Provyn S., Kichouh M., de Mey J., Murray R. (2018) Radiography of the distal extremity of the manus in the donkey foal: Normal images and quantitative characterization from birth to 2 years of age: A pilot study. Anat. Histol. Embryol. 47, 71-83; DOI 10.1111/ ahe. 12326

Waldern N. M., Wiestner T., Ramseier L. C., Amport C., Weishaupt M. A. (2013) Effects of shoeing on limb movement and ground reaction forces in Icelandic horses at walk, tölt and trot. Vet. J. 198 (SUPPL1), e103-e108; DOI 10.1016/j.tvil.2013.09.042

Walliser J., Walliser U., Blaß S., Offhaus J., Winter K. (2018) Relationen der Huf- und Kronbeinlänge zur Dicke der dorsalen Hufwand bei Pferden in unterschiedlichen Röntgenprojektionen. Pferdeheilkunde 34, 419-424, 10.21836/PEM20180502

Weishaupt M. A., Waldern N. M., Amport C., Ramseier L. C., Wiestner T. (2013) Effects of shoeing on intra- and inter-limb coordination and movement consistency in Icelandic horses at walk, tölt and trot. Vet. J. 198 (SUPPL1), e109-e1 13; DOI 10.1016/i. tvil.2013.09.043

White J. M., Mellor D. J., Duz M., Lischer C. J., Voute L. C. (2008) Diagnostic accuracy of digital photography and image analysis for the measurement of foot conformation in the horse. Equine Vet. J. 40, 623-628; DOI 10.2746/042516408X313625

Wilson A., Weller R., Pfau T., Vaux S., Agass R., Day P., Sherlock E. (2016) Foot placement of the equine forelimb: Relationship between foot conformation, foot placement and movement asymmetry. Equine Vet. J. 48, 90-96; DOI 10.1111/ evj. 12378 